\title{
Physical and chemical attributes of various cultivars of Plum fruit
}

\author{
Wasim Bilal $^{1 *}$, Muhammad Sajid ${ }^{1}$, Khalil Ur Rehman ${ }^{2}$, Naveed Ahmad ${ }^{1}$, \\ Azmat Ali Awan ${ }^{3}$, Babar Hussain ${ }^{1}$, Zakria Bacha ${ }^{1}$, Fazal Ur Rehman ${ }^{1}$, \\ Ahamad Naeem ${ }^{1}$, Qazi Shoaib Ali ${ }^{1}$ and Farida Bibi ${ }^{1}$ \\ 1. Department of Horticulture, The University of Agriculture, Peshawar, Pakistan. \\ 2. Agricultural Research Institute North, Mingora Swat, Pakistan. \\ 3. Agricultural Research Institute, Tarnab, Pakistan. \\ *Corresponding author's email: wasimbila1345@gmail.com \\ Citation \\ Wasim Bilal, Muhammad Sajid, Khalil Ur Rehman, Naveed Ahmad, Azmat Ali Awan, Babar Hussain, Zakria \\ Bacha, Fazal Ur Rehman, Ahamad Naeem, Qazi Shoaib Ali and Farida Bibi. Physical and chemical attributes of \\ various cultivars of Plum fruit. Pure and Applied Biology. Vol. 4, Issue 3, 2015, pp 353-361. \\ http://dx.doi.org/10.19045/bspab.2015.43011
}

Received: 13/06/2015 Revised: $14 / 07 / 2015$

Accepted: $23 / 07 / 2015$

\section{Abstract}

Cultivars of plum fruit could be best assessed by its physical and chemical qualities which are influenced by their genetic makeup and the climatic condition under which they are produced. In such regard, present study entitle as "Physical and chemical attributes of various cultivars of plum fruit" was elaborated at Agriculture Research Institute, North Mingora Swat during the year 2013, according to Completely Randomized Design (CRD). Significant differences were observed among all the attributes studied. The results revealed that the highest fruit weight $(62.55 \mathrm{~g})$, fruit volume $(62.44 \mathrm{ml})$, fruit length $(50.39 \mathrm{~mm})$, stone weight $(2.48 \mathrm{~g})$, stone thickness $(11.99 \mathrm{~mm})$ were recorded in plum cultivar President, whereas the lowest fruit weight $(27.44 \mathrm{~g})$, fruit volume $(31.22 \mathrm{ml})$, fruit length $(40.20 \mathrm{~mm})$, fruit diameter $(35.25 \mathrm{~mm})$, stone weight $(1.11 \mathrm{~g})$, stone thickness $(7.23 \mathrm{~mm})$ and shelf life $(9.77$ days) were noted in plum cultivar D-Agen. However, the maximum fruit diameter $(49.39 \mathrm{~mm})$ was recorded in fruits taken from cultivar Ruby red. While the highest total soluble solids (16.38 brix) were observed in D-agen. Cultivar Blufre fruits were observed with the highest stone length $(29.71 \mathrm{~mm})$ and shelf life (23.78 days). It could be inferred from the current findings that plum cultivar President should be grown under the agro climatic conditions of district $S$ wat for good quality fruit production.

Key words: Prunus domestica (European Plum); Attributes; Cultivars; Climatic condition.

\section{Introduction}

Plum is a drupe or stone fruit belonging to the family Rosacea of the genus Prunus. There are 15 cultivated species of plum. Among them the most common are Punus salicina (Japanese plum) and Prunus domestica (European Plum) [1]. Plums are the fruit of temperate zone, but however they are grown throughout the globe, from the temperate climatic conditions of Ciberia to that of subtropical climatic conditions of the Mediterranean regions [2].

China has taken a lead in the production of plum fruits in the overall world with total annual production of 4,635,600 metric tons [3]. Pakistan has offered 6700 hactares of its 
total land for producing 56200 tonnes of plum fruits. Among all the provinces, Balochistan is on the rank $1^{\text {st }}$ with total annual production of 28900 tonnes of fruits on the land of 3700 hactares; While Khyber Pakhtunkhwa is producing 27000 tonnes of fruits on the land of 3000 hactares [4]. Moreover, in Khyber Pakhtunkhwa $17 \%$ of plum fruits are produced by district Swat [5].

The great valley of swat is blessed with pure natural clean environment and weather which is well suited for the production of plum, peach, apricot, apple and pear. The maximum temperature in the valley may rise up to $38{ }^{\circ} \mathrm{C}$ with a relative humidity of 80 $90 \%$ in the months of July and August. And the average low temperature of the valley could remain up to $2-5{ }^{\circ} \mathrm{C}$ and might go down even below $0^{\circ} \mathrm{C}$ during the winter season. Moreover, Frost occurs from December to February. Fruit produced here have high economic value and are liked for their good color and sweet taste, helping the producers to earn more for their livings. Most of the fruits produced in the valley are exported to markets within the country and outside it [6].

Plum is commercially propagated through asexual or vegetative means of reproduction. The rootstocks used for budding of plum are peach, plum, apricot and almond. Normally methods of T-budding and chip budding are practiced for the successful propagation of plum scion on peach rootstock $[1,7]$.

Plum could be used both in fresh and processed form. Plum processed products include pulp, dried fruit, candied fruit, frozen fruit, jams and alcoholic beverages. Due to their taste and dietary value they are liked and consumed by children and adult of various age groups. Plum fruit contain sugars, organic acids and other compounds important from the dietary point of view. It is a major fruit of export, both fresh and frozen [8]. Relatively Plums are characterized with high antioxidant capacity, higher than e.g. apples, oranges or strawberries [9].

Plums are typically harvested firm-mature and ripened prior to its use. A mature fruit gains good quality when it is ripened off the tree. As the fruit reaches near to its maturity due to a rapid increase in its size, change in skin and flesh color, flesh softening and flavor changes are very obvious [10]. Usually the best way to determine ripening of the stone fruit is to taste it. All the stone fruits are harvested without stem except sweet cherries. The fruit should be harvested by holding it in the palm of hand rather to pull it with fingers [11].

Appearance and taste of fruit are the foremost important traits examined by consumer before purchasing it which is correlated with solid contents and acidity of the fruit [12]. Acceptance of plum fruits by the consumer is directly associated with harvest date and maturation stage of fruit and supply must be correlated with their shelf life. When plum fruit is available for longer time in the market, the more it is competitive in means of price in contrast to cultivars having a short storage life [12, 13]. Harvesting of fruit at optimal time assures good quality of fruit with no unnecessary losses which is caused by fungal diseases or physiological disorders $[14,15]$.

Keeping in view the dietary importance of plum fruit and as a source of income for many, a research study was conducted on four different cultivars of plum fruit at ARINM swat. They were examined for evaluation of their physical and chemical attributes. As these quality characteristics are the basis for the selection of best quality fruit cultivars. Moreover, they were kept at room temperature to record their shelf life persistency and finally, to come up with the cultivars that could be kept for longer time which would be helpful in transporting them to distant markets. 


\section{Materials and Methods}

To investigate the physical and chemical attributes of various plum cultivars, an experiment was conducted at Agricultural Research Institute North Mingora Swat, during the year 2013. The experiment was carried out with Completely Randomized Design (CRD), replicated three times. In current research fruits of selected plum cultivars i-e D-Agen, President, Blue Free, Ruby Red were subjected for the evaluation of physical and chemical attributes. Four different cultivars of plum were selected for this study. Fruits of the selected four cultivars were picked from trees at their physiological maturity stage and carried to the Laboratory of the same research institute for evaluation of their physical and chemical attributes. In addition, samples of each cultivar of plum fruit were kept at room temperature for the evaluation of their shelf life in days. The fresh weight of randomly selected plum fruits of each cultivar were taken with the help of Digital weight balance and then the averages were calculated. Then volume of randomly selected fruits in each cultivar was taken with the help of graduated beaker by water displacement method. In addition, length of randomly selected fruits in each cultivar was measured by using digital vernier caliper. Moreover, diameter of the randomly selected fruits was measured with the help of digital vernier caliper. Furthermore, total soluble solid of fruits were determined by using hand refractrometer at room temperature. The drops of each representative samples were put on the dry prism of refrectrometer which was cleaned prior with distal water, dried with tissue paper each time for every new sample and the readings were noted for the entire samples [16]. Weight of the fruit seed (stones) was taken with the help of digital weight balance. Stone length was measured for each fruit with the help of digital vernier caliper. The diameter of each fruit stone in each cultivar was measured by using a digital vernier caliper. Finally, the shelf life of each fruit in each cultivar was observed at room temperature and their means were calculated by counting the number of days from picking to last date. All the noted data for each parameter among the fruit cultivars were subjected to analysis of variance (ANOVA) process to verify differences between various cultivars. Least significant difference (LSD) test was used for the significantly different means. Computer statistical software Statistixs 8.1 was used for calculating ANOVA and LSD [17].

\section{Results and Discussion Fruit weight (gm)}

The mean values for fruit weight revealed that the maximum fruit weight $(64.89 \mathrm{gm})$ was observed in variety "Ruby red" followed by variety, President (62.55 gm) and the minimum (27.44 gm) was observed in "D -Agen". The current results are in accordance with the results of [2] who reported that fruit weight ranged from 46.71 g (Obilnaja) to $91.26 \mathrm{~g}$ (Black Diamond) and fruit weight for cultivar "president" was recorded $63.79 \mathrm{~g}$. [18] observed in a study fruit weight of plum cultivar 'President' as $57.04 \mathrm{~g}$ while [19] in a study recorded weight for president cultivar as $74 \mathrm{~g}$. Moreover, [20] also reported that fruit weight for F1 hybrid cultivars ranged from $25.31 \pm 1.27$ to $57.62 \pm 2.11$. Fruit size is the main quantitative hereditary factor that determines yield, fruit quality and consumer acceptability. The variation may be due to different soil and climatic conditions, management practices and cultivars being selected [12].

\section{Fruit volume (ml)}

The mean values for fruit volume showed that the maximum fruit volume $(62.44 \mathrm{ml})$ was observed in variety "President" and the minimum $(31.22 \mathrm{ml})$ was observed in " $\mathrm{D}$ - 
Agen". The fruit weight and size might affect the fruit volume, as from the current study it could be inferred that the fruit having higher weight may have higher volume.

\section{Fruit length (mm)}

The mean Table 1 showed that the maximum fruit length $(50.39 \mathrm{~mm})$ was recorded for variety, President while the minimum $(40.2 \mathrm{~mm})$ was recorded for Dagen. [2] stated that fruit length of various cultivars of plum ranged 40.07- $55.94 \mathrm{~mm}$, among them cultivar president was noted as $51.18 \mathrm{~mm}$, which is in accordance with the result of current study. The variation in fruit length may vary among different cultivars due to size, shape and structure of the fruit.

\section{Fruit diameter (mm)}

It was concluded from the mean Table 1 that the maximum fruit diameter $(49.39 \mathrm{~mm})$ was recorded for variety, Ruby red while the minimum $(35.25 \mathrm{~mm})$ was observed for DAgen. Fruit diameters for different cultivars were also observed by [2] in a study that ranged $42.09-56.09 \mathrm{~mm}$. It is obvious to state that all cultivars do not possess the same physical attributes because the shape size and vigor of the fruit is not same for each and every cultivar.

\section{Total soluble solids (TSS ${ }^{\circ}$ Brix)}

Mean Table 1 for the total soluble solids shows that the maximum (16.38) total soluble solids were determined in variety, D-Agen and the minimum (9.77) in Bluefre. The present results of total soluble solids are in comparison with the result of a research findings [21] that ranged 10-18 ${ }^{\circ}$ Brix , in which a variety 'bluefre' having $10^{\circ}$ Brix is somewhat related to the current findings. However it could to be stated that fruit size and dry matter contents are highly variable which depend upon the cultural practices and season. In the previous years from the same orchard another findings claimed to have $14{ }^{\circ}$ Brix for the same cultivar 'blufre' [22].

\section{Stone weight (gm)}

The mean values for stone weight reveals that higher (2.48 gm) stone weight was recorded for variety President and lower (1.11 gm) for D-Agen. The current findings seems to be similar with the results obtained for F1 hybrid cultivars ranging from $1.20 \pm$ 0.05 to $2.01 \pm 0.02 \mathrm{~g}$ [23]. It could be stated that each and every cultivar of plum fruit has a seed that is different in size which obviously vary in weight due to difference in their genetic makeup. Furthermore, difference in stone weight of the fruits among the same cultivar might be correlated with size and vigor of the fruit, which might be affected by the cultural practices and climatic condition.

\section{Stone length $(\mathbf{m m})$}

The mean values for stone length showed that the maximum $(29.71 \mathrm{~mm})$ stone length was recorded for variety (bluefre) and the minimum (17.55 $\mathrm{mm})$ for Ruby red. In different studies length of stones is observed differently for various cultivars. As in a study it ranged 30-30.35 mm [21]. Another study also reported to have stone length for various cultivars ranged 14.42-22.19 mm [24]. Which assures that stone length for various cultivars mostly differs.

\section{Stone thickness ( $\mathbf{m m})$}

The mean value for stone thickness shows that the maximum $(11.99 \mathrm{~mm})$ stone thickness was observed for variety, President and the minimum $(7.23 \mathrm{~mm})$ for D-Agen. [24] reported that stone thickness for plum cultivars studied ranged 5.86-8.55 $\mathrm{mm}$ that weighted $0.26-0.99 \mathrm{~g}$, which are in contrast with the current findings. It could be drawn from the comparison that weight of the stone affects the thickness of the stone.

\section{Shelf life of fruit (days)}

The mean value for shelf life of fruits showed that the maximum (23.78) days life 
Table 1. Parameters of fruits as recorded for various cultivars

\begin{tabular}{lccccc}
\hline & \multicolumn{3}{c}{ Cultivars } & \\
\cline { 2 - 4 } & D -Agen & President & Blue free & Ruby red & LSD $\boldsymbol{\alpha ~ 0 . 0 5}$ \\
\hline Fruit weight $(\mathrm{g})$ & $27.44 \mathrm{c}$ & $62.55 \mathrm{a}$ & $35.11 \mathrm{~b}$ & $64.89 \mathrm{a}$ & 3.9857 \\
Fruit volume $(\mathrm{ml})$ & $31.22 \mathrm{~b}$ & $62.44 \mathrm{a}$ & $34.57 \mathrm{~b}$ & $62.22 \mathrm{a}$ & 6.67671 \\
Fruit length $(\mathrm{mm})$ & $40.2 \mathrm{c}$ & $50.39 \mathrm{a}$ & $47.1 \mathrm{~b}$ & $46.68 \mathrm{~b}$ & 2.2689 \\
Fruit diameter $(\mathrm{mm})$ & $35.25 \mathrm{c}$ & $47.31 \mathrm{~b}$ & $36.44 \mathrm{c}$ & $49.39 \mathrm{a}$ & 1.5156 \\
TSS (brix) & $16.38 \mathrm{a}$ & $14.03 \mathrm{~b}$ & $9.77 \mathrm{c}$ & $10.51 \mathrm{c}$ & 1.3114 \\
Stone weight $(\mathrm{g})$ & $1.11 \mathrm{c}$ & $2.48 \mathrm{a}$ & $1.89 \mathrm{~b}$ & $1.167 \mathrm{c}$ & 0.1242 \\
Stone length $(\mathrm{mm})$ & $21.23 \mathrm{c}$ & $27.09 \mathrm{~b}$ & $29.71 \mathrm{a}$ & $17.55 \mathrm{~d}$ & 1.0887 \\
Stone thickness & $7.23 \mathrm{~d}$ & $11.99 \mathrm{a}$ & $8.87 \mathrm{c}$ & $9.42 \mathrm{~b}$ & 0.5475 \\
(mm) & & & & & \\
Shelf life of fruit & $9.77 \mathrm{~d}$ & $14.22 \mathrm{c}$ & $23.78 \mathrm{a}$ & $17.66 \mathrm{~b}$ & 2.2625 \\
(days) & & & & \\
\hline
\end{tabular}

Means not followed by the same letters are significantly different using LSD Test at 5\% level of probability.

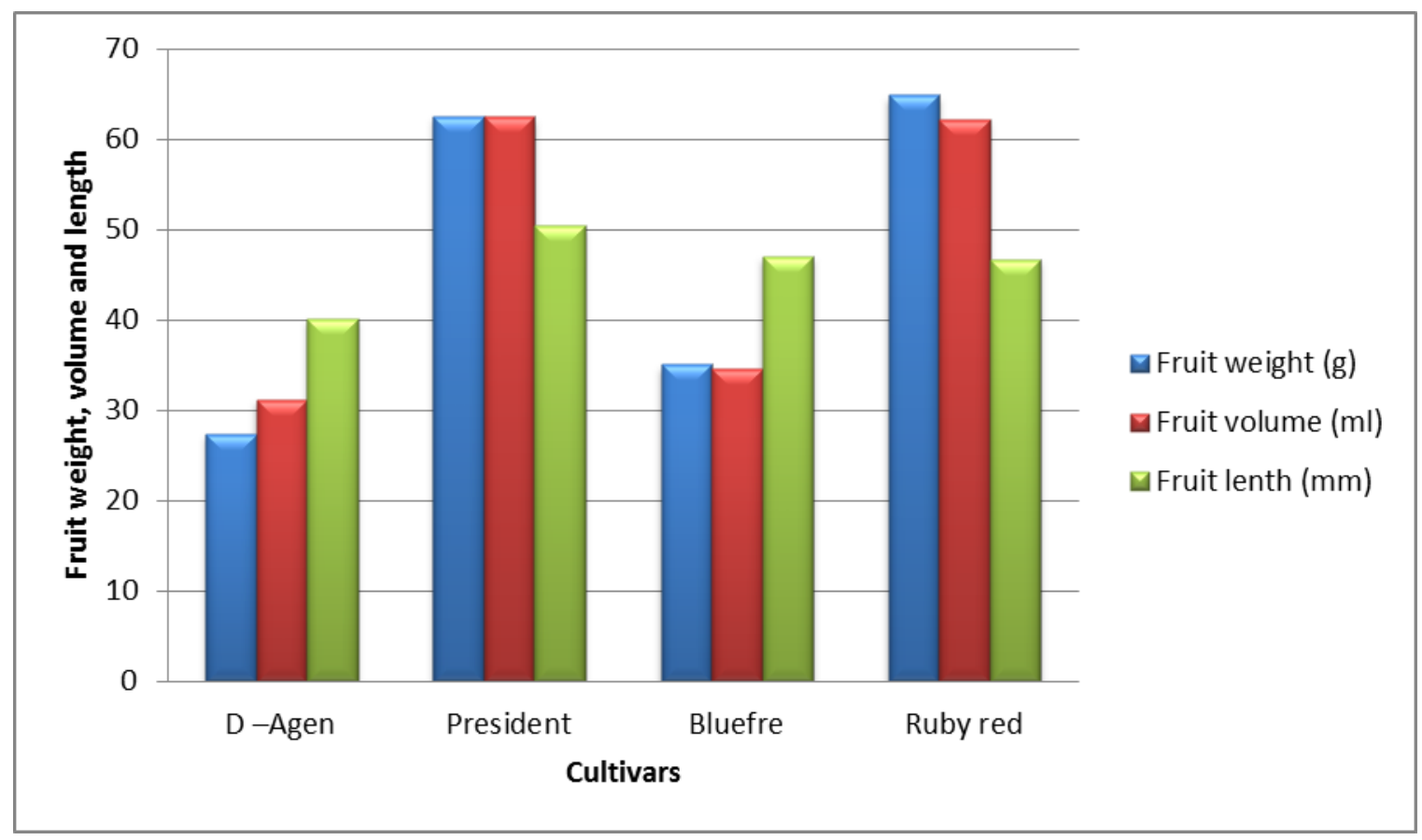

Fig. 1. Showing Fruit weight, Fruit volume and Fruit length of various cultivars 
Bilal et al.

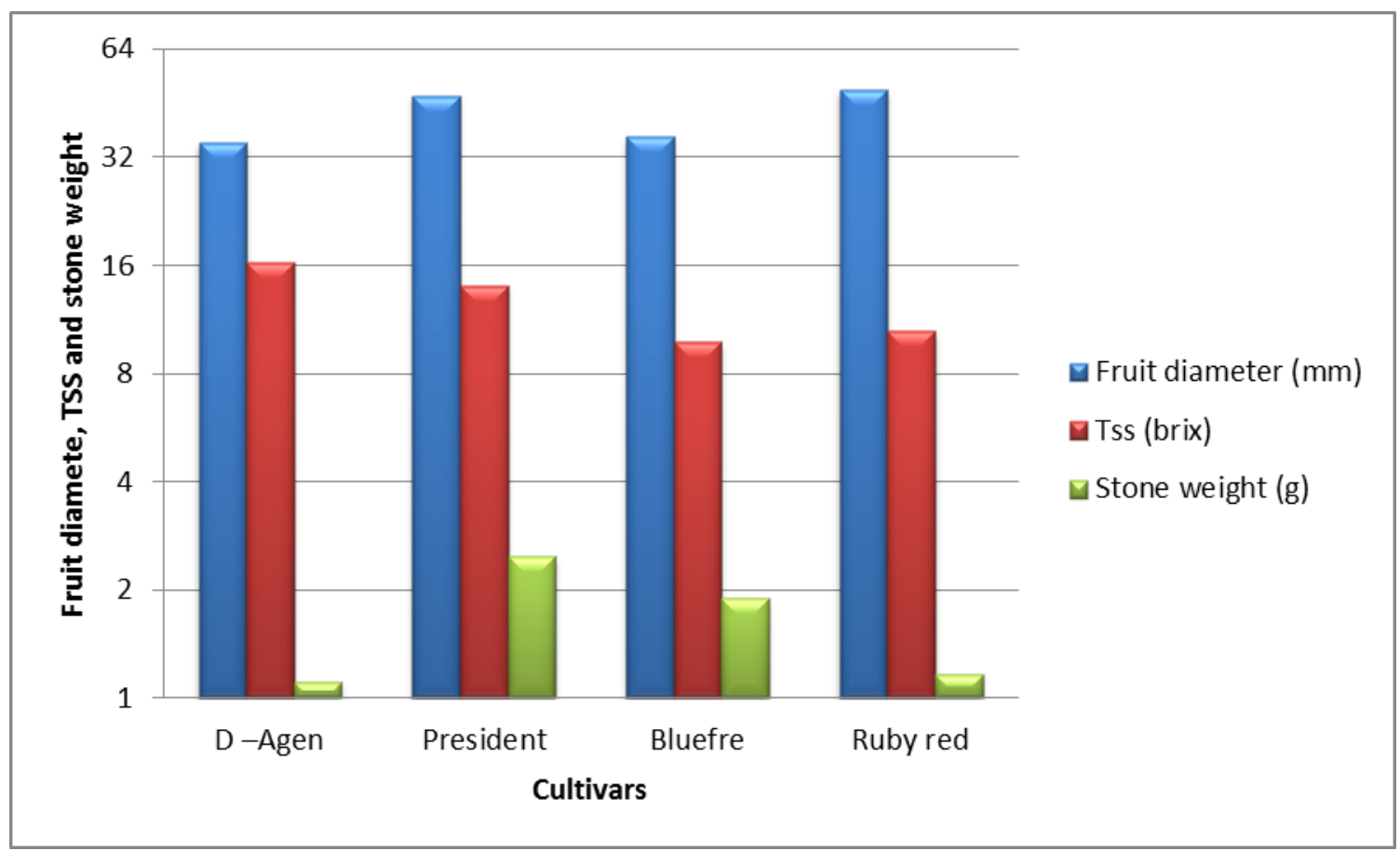

Fig. 2. Showing Fruit diameter, Total soluble solids and Stone weight of various cultivars

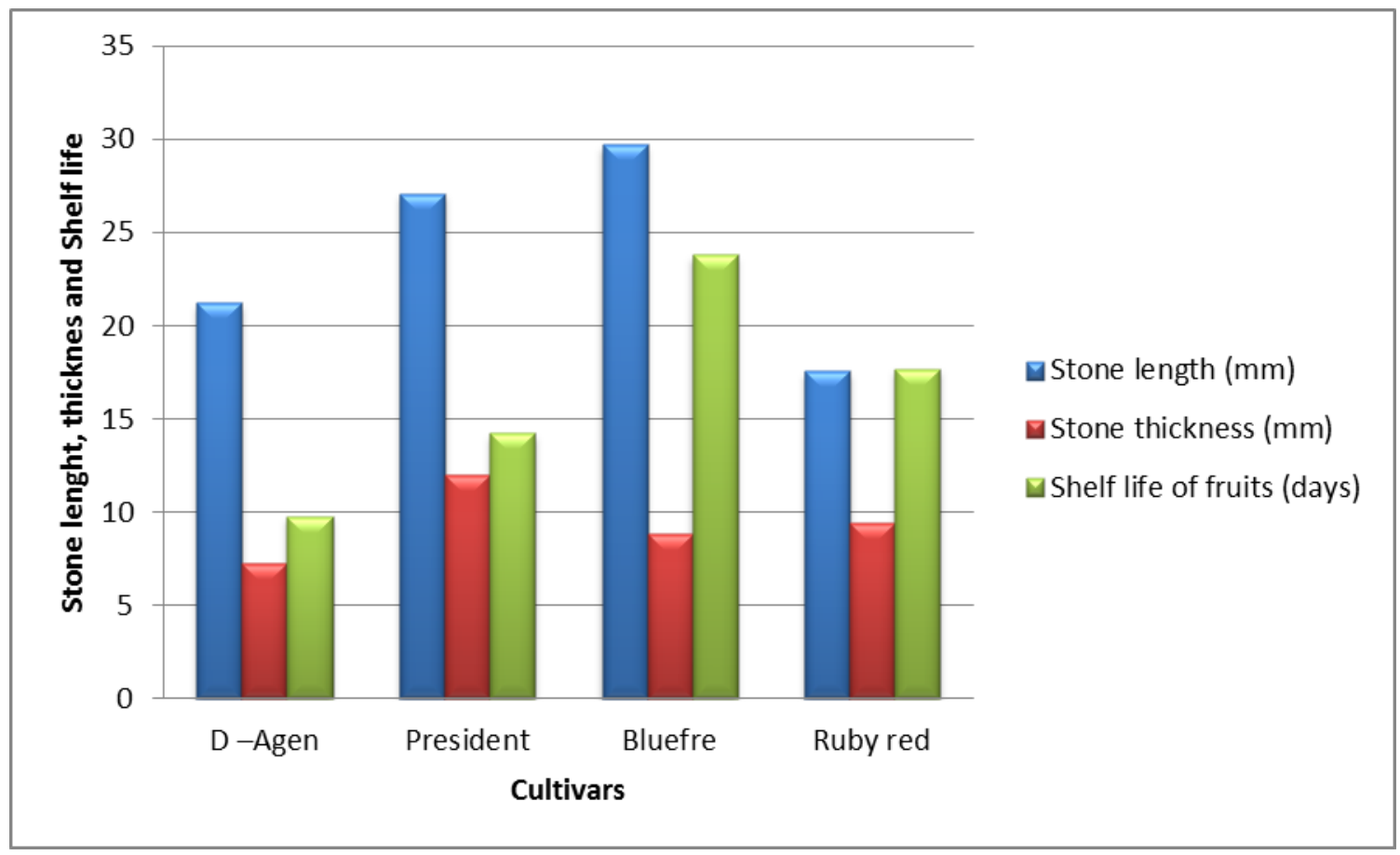

Fig. 3. Showing Stone length, Stone width and Shelf life of fruits of various cultivars 


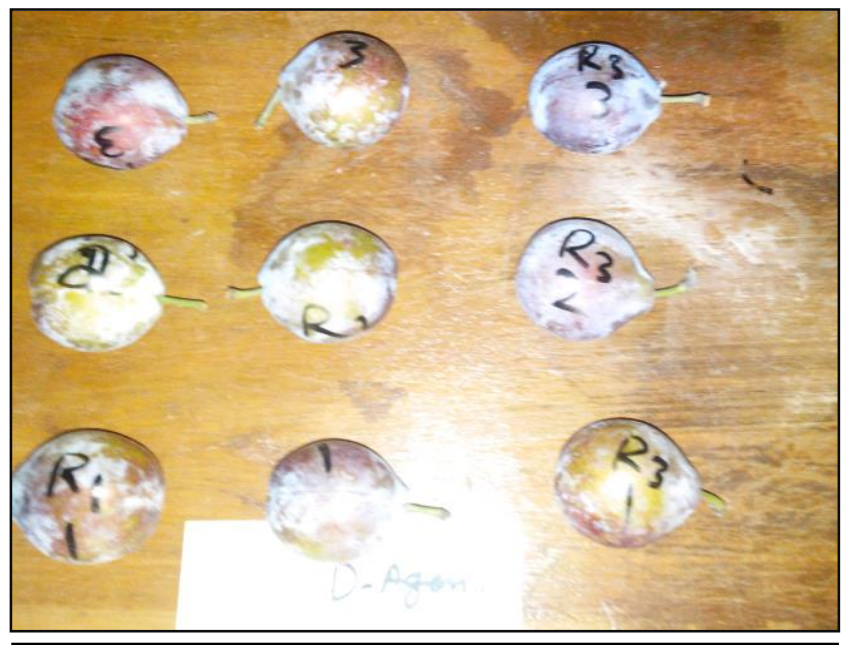

Fig. 4. Plum fruit cultivar D-Agen

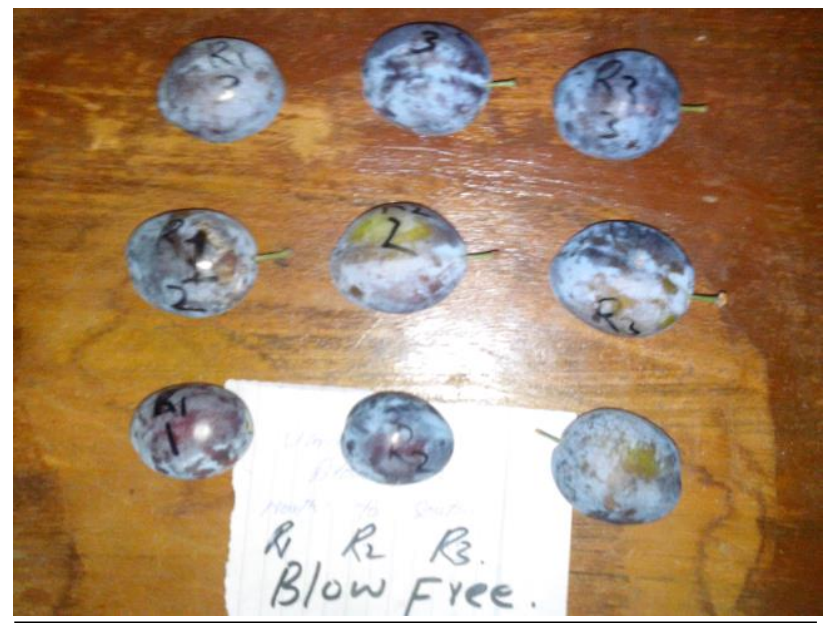

Fig. 6. Plum fruit cultivar bluefre

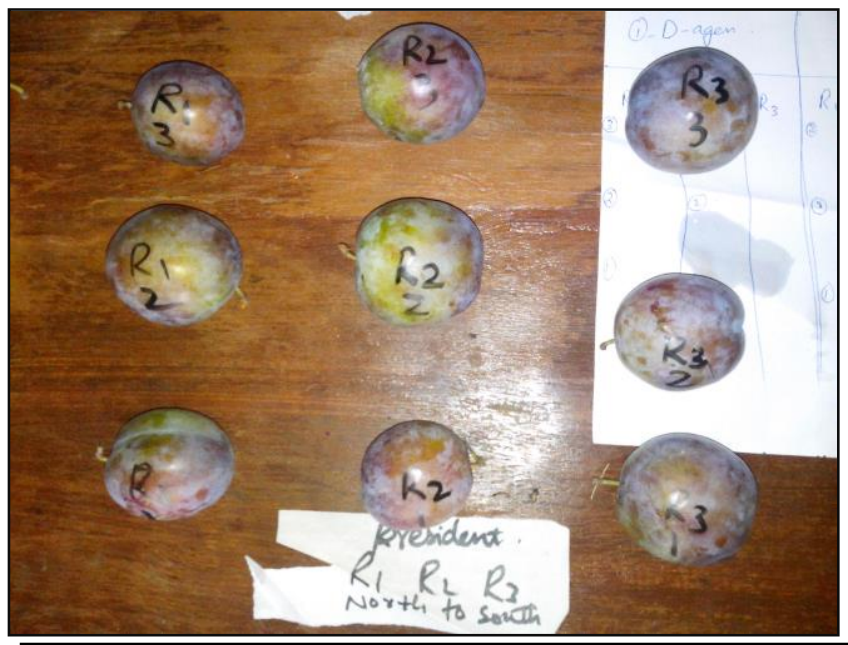

Fig. 5. Plum fruit cultivar President

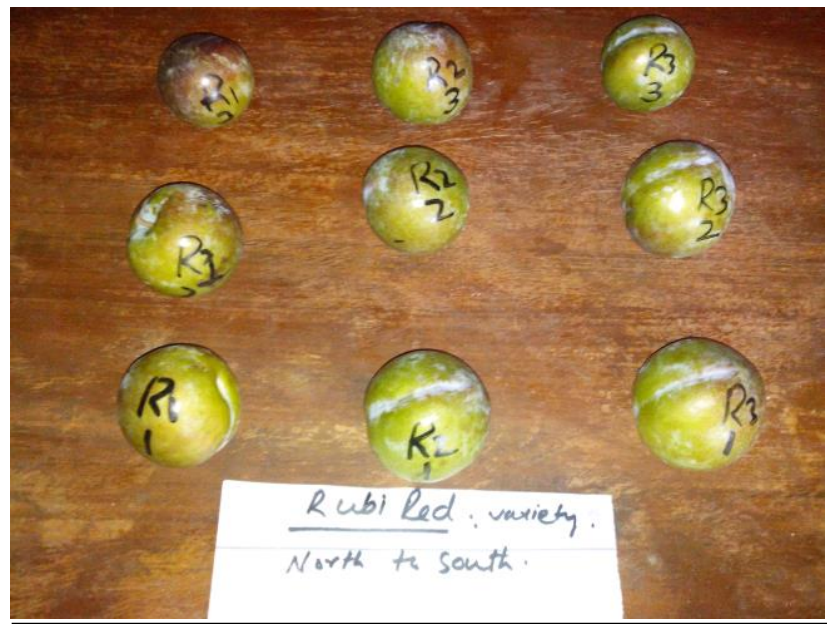

Fig. 7. Plum fruit cultivar Rubi red

was observed for variety, Bluefre and minimum (9.77) days for D-Agen. Every cultivar of plum fruits has its own keeping period which might be related to the solid contents of the fruit, temperature and the stage in which the fruits are harvested. [25] observed difference in shelf life of different cultivars of plum fruit and they were characterized to have short, medium and long shelf life.

\section{Conclusion and Recommendation}

It was conclude from the current study that president cultivar of plum carried mostly good quality attributes which are enough for 
its fruit to attract the consumer in the market. Furthermore, Cultivar D-Agen has the shortest shelf among the four cultivars selected for the study while cultivar Blufre has the longest shelf life thus could be available for extended period of time in the market and is able to transport to distant markets with minimum fruit loss.

Following recommendations could be made on the basis of conclusion.

Plum cultivar President should be grown under the agro climatic conditions of Swat for quality fruit production while for distant markets and shipments cultivar Blufre is recommended.

\section{References}

1. Malik MN (2006). Horiculture. Fruit crops. Plums. National book foundation; Islamabad. 474-76p.

2. Son F (2010). Determination on quality characteristics of some important Japanese plum (Prunus Salicina Lindl.) cultivars grown in Mersin-Turkey. African J Agri Res 5(10): 1144-1146.

3. Liu W (2007). Genetic Diversity and Phylogenetic Relationships among Plum Germplasm Resources in China Assessed with Inter-simple Sequence Repeat. Markers 132(5): 619-628.

4. Agri. Stat. Pak (2010-11). Plums. Ministry for Food, Agriculture and Livestock, Economic Wing, Islamabad, Pakistan. Table 53. P. 97.

5. GOP (2009). Agricultural Statistics of Pakistan. District wise Area and Production of Plums. Economic Wing, Islamabad. 190-191p.

6. Rauf MA, Khan A \& Rehman KU (2010-2011). Annual progress report. Agri. Res. Institute Mingora Swat 1-2.

7. Chandler WH (1965). Deciduous orchards. Stone fruits. Plums. lea and febiger 4(17): 338-352pp.

8. Grzyb ZS \& Rozpara E (2000). Modern plum growing. Hortpress.
9. Kayano S, Kikuzaki H, Fukutsaka N, Mitani T \& Nakatani N (2002). Antioxidant activity of prune (Prunus domestica L.) constituents and a new synergist. J Agric Food Chem 50: 37083712.

10. Kader AA \& Mitchell FG (1989a). Maturity and quality. Peaches, plums and nectarines: growing and handling for fresh market. Uni California Depart Agri Nat Res 3331: 191-196.

11. Roper TR, Mahar DL \& Mcmanus PS (1998). Harvesting. Growing apricots, cherries, peaches and plums in Wisconsin. Cooperative Extension. Univ Wisconsin A3639: P. 13.

12. Crisosto CH, Garner D, Crisosto GM \& Bowerman E (2004). Increasing 'Blackamber' plum (Prunus salicina L) consumer acceptance. Postharvest Biol Technol 34: 237-244.

13. Zuzunaga M, Serrano M, MartınezRomero D, Valero D \& Riquelme F (2001). Comparative study of two plum (Prunus salicina Lindl.) cultivars during growth and ripening. Food Sci Tech Int 7: 123-130.

14. Taylor MA, Rabe E, Dodd MC \& Jacobs G (1993). Influence of sampling date and position in the tree on mineral nutrients, maturity and gel breakdown in cold stored 'Songold' plums. Sci Hort 54: 131-141.

15. Crisosto $\mathrm{CH}$, Mitchell FG \& Johnson S (1995). Factors in fresh market stone fruit quality. Postharvest News Inf 6: 17-21.

16. AOAC (1995). Official methods of analysis $\left(16^{\text {th }}\right.$ ed). Washington, DC: Association of Official Analytical Chemists.

17. Steel RGD \& Torrie JH (1980). Principles and procedures of statistics, second edidtion, New York: McGraw-Hill. 
18. Karamursel OF, Sevik I, Sarisi HC, Kocal H \& Ozturk FP (2007). Adaptation of European plums (Prunus domestica) under egirdir ecological conditions. 5th Turkish Nat Hort Congress 1: 481-485.

19. Moghaddam EG, Ava SH, Akhavan S, \& Hosseini S (2011). Phenological and pomological characteristics of some plum (Prunus spp.) cultivars grown in Mashhad, Iran. Crop Breed J 1(2): 105108.

20. Milosevic T \& N Milosevic (2012). Main physical and chemical traits of fresh fruits of promising plum hybrids (Prunus domestica L.) from Cacak (Western Serbia). Rom Biotech Letters 17(3).

21. Walkowiak-Tomezak D, Regula J \& Lysiak G (2008). Physico-chemical properties and antioxidant Activity of selected plum cultivars fruit. Acta Sci Pol Technol Aliment 7(4): 15-22.

22. Lysiak G (1999). Evaluation of productivity of 10 plum cultivars growing on two rootstocks. Pr. Kom. Nauk Roln. Kom. Nauk Lesn. PTPN 87: 95-101.

23. Milosevic T \& Milosevic N (2011). Quantitative analysis of the main biological and fruit quality traits of $\mathrm{f} 1$ plum genotypes (Prunus domestica L.). Acta Sci Pol Hort Cultus 10(2): 95-107.

24. Gunes M (2003). Some local varieties grown in tokat province. Pakistan $J$ applied Sci 3(5): 291-295.

25. Vangdal E, Flatland S \& Nordbo R (2007). Fruit quality changes during marketing of new plum cultivars (Prunus domestica L.). Hort Sci (Prague) 34(3):91-95. 